\title{
INFLUENCE OF SEASONAL DROUGHT ON ECOSYSTEM WATER USE EFFICIENCY IN A SUBTROPICAL EVERGREEN CONIFEROUS PLANTATION
}

\author{
MI, N. ${ }^{1}-$ WEN, X. F. ${ }^{2 *}-$ CAI, F. ${ }^{1}-$ ZHANG, Y. S. ${ }^{1}-$ WANG, H. M. ${ }^{2}$ \\ ${ }^{1}$ Institute of Atmospheric Environment, China Meteorological Administration (Shenyang), \\ Shenyang 110166, China \\ ${ }^{2}$ Key Laboratory of Ecosystem Network Observation and Modeling, Institute of Geographic \\ Sciences and Natural Resources Research, Chinese Academy of Sciences, Beijing 100101, China \\ (phone: +86-24-83187017; fax: +86-24-83893258) \\ *Corresponding author \\ e-mail:wenxf@igsnrr.ac.cn \\ (Received $12^{\text {th }}$ Oct 2015; accepted $5^{\text {th }}$ Mar 2016)
}

\begin{abstract}
Seasonal drought (low precipitation combined with high atmospheric temperature) typically occurs during the active vegetative growth season in subtropical regions of southeast China. We examined the responses of water use efficiency (WUE) and its components, gross primary productivity (GPP) and evapotranspiration (ET), to water limitations and high atmospheric temperature $\left(T_{\mathrm{a}}\right)$ in a subtropical evergreen coniferous plantation. The effect of high temperature and low water availability on the water use efficiency (WUE) at the site was analyzed using six years (2003-2008) of eddy covariance flux observations. During the active growing season (June-August), GPP and ET did not decrease remarkably and successively unless extreme drought occurred, i.e. mean soil relative extractable water decreased below 0.4. Low precipitation and high $T_{\mathrm{a}}\left(26-32^{\circ} \mathrm{C}\right)$ at the peak of the active growing season decreased GPP. Furthermore, the response of water consumption (i.e. ET) to high $T_{\mathrm{a}}$ and drought lagged behind that of carbon fixation (i.e. GPP). Whether daily WUE increases or decreases in response to drought depends on temperature. For the present study site, at daily time scale, variations of WUE during the active growing season were determined mostly by air temperature while at longer (annual) time scales the influence of solar radiation may exert greater control over interannual variation in WUE than air temperature.
\end{abstract}

Keywords: evergreen coniferous plantation, evapotranspiration, gross primary production, seasonal drought, water use efficiency

\section{Introduction}

When considering the relationship between average climate and forest productivity among sites - or inter-annual variations within one site - water and carbon (C) fluxes and, therefore, productivity of forest ecosystems are strongly influenced by drought (Granier et al., 2007). Since water and C fluxes are strongly linked by their passage through the stomata, water use efficiency (WUE), the ratio of carbon dioxide $\left(\mathrm{CO}_{2}\right)$ assimilation to water losses, has been identified as an effective integral trait for assessment of ecosystem response to drought (Reichstein et al., 2007; Linares and Camarero, 2012). Therefore, understanding ecosystem WUE and its key controlling processes in response to drought by using long-term observations is helpful to project drought-terrestrial $\mathrm{C}$ feedbacks. 
Drought stress occurs whenever soil water drops below a threshold that induces restrictions to growth and transpiration (Bréda et al., 2006). Transpiration, gross photosynthesis and respiration decrease sharply when the soil relative extractable water (REW) drops below 0.4 (Granier et al., 2007). Repeated drought induces a reduction in leaf area index (LAI) (Battaglia et al., 1998; Zhang et al., 2005) that subsequently decreases gross primary production (GPP) (Law et al., 2002; Hoff and Rambal, 2003). Drought in European forests during an extremely dry year (2003) reduced annual tree growth and had consequences in subsequent years (Granier et al., 2007).

High atmospheric temperatures ( $\left.T_{\mathrm{a}}\right)$ have been shown to adversely affect GPP in many forest ecosystems. For example, Griffis et al. (2003) found that boreal conifers experienced a pronounced mid-season decline in GPP. Grant et al. (2001) showed that the GPP of boreal black spruce declined under higher $T_{\mathrm{a}}$. The sensitivity of GPP to high $T_{\mathrm{a}}$ in forests may be due to biochemical or stomatal factors (Grant et al., 2005). Méthy et al. (1997) found degradation of photosystem II photochemical efficiency in Pinus halapensis only at temperatures $>35^{\circ} \mathrm{C}$, which is well above those at which GPP becomes constrained. However stomatal conductance $\left(g_{1}\right)$ of most vegetation (e.g. boreal conifers and deciduous trees) has been frequently observed to decline under the higher atmospheric vapor pressure deficits (VPDs) (Grelle et al., 1999; Ohta et al., 2001; Wang et al., 2009, 2012) that can occur at temperatures $>25^{\circ} \mathrm{C}$. Reduced $g_{1}$ caused by higher VPD limits a plant's ability to use light for photosynthesis because of reduced $\mathrm{CO}_{2}$ concentrations inside leaves (Schulze et al., 1987). Transpiration is also reduced by stomatal control and affects leaf energy balance (Baldocchi, 1997). Consequently, there is an increase in leaf temperature, which promotes photorespiration and affects electron transport and carboxylation capacity, thereby potentially reducing C gain (Harley and Tenhunen, 1991; Baldocchi, 1997).

Empirical evidence has shown strong coupling between transpiration and photosynthesis, and the effect that drought can have on both processes (Bernier et al., 2006). Moreover, temperate and subtropical forest ecosystems have been shown to have different relationships between GPP and evapotranspiration (ET) (Yu et al., 2008). For temperate forest ecosystems, GPP was significantly correlated with ET at different temporal scales, showing a strong linear relationship between $\mathrm{C}$ gain and water loss. For subtropical forest ecosystems, the relation between GPP and ET was nonlinear indicating that the coupling between GPP and ET was weak under the changing environmental variables (Yu et al., 2008). Ruehr et al. (2012) also reported that $\mathrm{C}$ and water fluxes were tightly coupled, but became less so during drought for a young ponderosa pine forest. The ratio of GPP to ET, expressed as WUE, was found to decrease slightly during severe drought in a European forest in the summer of 2003 (Reichstein et al., 2007). As described by Reichstein et al. (2002), this pattern challenges many current ecosystem model formulations in which pure stomatal control implies increasing WUE under soil drying conditions (Schulze et al., 2005). Indeed there are also observations that WUE increases during the seasonal drought (Vickers et al., 2012).

Due to the effect of the subtropical continental monsoon climate, the mid-subtropical region in southeast China is rich in water and heat resources. However, the lower atmosphere layer of this region is controlled by a West Pacific subtropical high pressure 
system and a descending airflow prevails in summer, which often leads to difficulty in forming precipitation (Sun et al., 2006). Hence, seasonal drought (less precipitation combined with high air temperature) usually occurs during the active vegetative growth season, which is typical in subtropical regions of southeast China (Sun et al., 2006; Yu et al., 2008; Wen et al., 2010). The changing precipitation regime (such as rainfall deficit) accompanied by increased air temperature has a profound impact on ecosystem $\mathrm{C}$ exchanges (e.g. Ciais et al., 2005; Niu et al., 2011). Some studies have also reported that during dry seasons in wet-dry regions, many tree species do not suffer from significant water stress as a result of one or several adaptive mechanisms (Eamus and Prior, 2001). To date, the behavior of whole ecosystems in the humid climate zone in response to seasonal drought has not been thoroughly investigated.

The objectives of this study were: (i) to describe the seasonal and inter-annual patterns of WUE for a subtropical plantation forest; (ii) to investigate the coupling relationship between GPP and ET and their dependence on $T_{\mathrm{a}}$ and explain the reason for decreasing WUE during the peak of the active growing season; (iii) to explore whether decreased soil water content led to decreased $\mathrm{C}$ fixation during the active growing season.

\section{Materials and methods}

\section{Study site}

The study site in ChinaFLUX is located at the Qianyanzhou Experimental Station of the Chinese Ecosystem Research Network in southeast China $\left(26^{\circ} 44^{\prime} \mathrm{N}, 115^{\circ} 03^{\prime} \mathrm{E}\right.$ and $102 \mathrm{~m}$ a.s.1.). The vegetation is mainly evergreen coniferous trees planted after 1985 and the dominant species include slash pine ( $P$. elliottii), Masson pine ( $P$. massoniana) and Chinese fir (Cunninghamia lanceolata) with an average canopy height of $13 \mathrm{~m}$ (Wen et al., 2010). The summer maximum LAI is $5.6 \mathrm{~m}^{2} \mathrm{~m}^{-2}$ and tree density is 1463 stems ha ${ }^{-1}$. The study site is in a typical subtropical monsoon climate region with predominant south-southeast winds in summer and north-northwest winds in winter. With the aid of FSAM (flux source area model), Mi et al. (2006) indicated that the flux footprint was 120 $\mathrm{m}$ under unstable conditions, while it was $1655 \mathrm{~m}$ under stable conditions. The red soil is weathered from red sand rock, and the soil texture is divided into 2.0-0.05 (17\%), $0.05-0.002(68 \%)$ and $<0.002 \mathrm{~mm}(15 \%)$, with $\mathrm{pH} 4.7$ and organic matter content of $2.14 \%$ (Wang et al., 2004). The average annual air temperature over 20 years (1985-2007) was approximately $17.9^{\circ} \mathrm{C}$ and mean annual precipitation was $1475 \mathrm{~mm}$ (Wen et al., 2010). Further detailed descriptions of the region are available in the literature (Wen et al., 2006, 2010; Zhang et al., 2011a, 2011b).

\section{Flux measurements and data processing}

Ecosystem ET and C exchange were measured continuously at $39.6 \mathrm{~m}$ using the eddy covariance (EC) technique from late August 2002. Briefly, the EC measurement setup consisted of a three-dimensional sonic anemometer (Model CSAT3, Campbell Scientific Inc., Logan, UT, USA) for wind speed and temperature measurement and an open-path 
infrared absorption gas analyzer (Model LI-7500, Licor Inc., Lincoln, NE, USA) for measurement of $\mathrm{CO}_{2}$ and water vapor concentration. The signals from the $\mathrm{EC}$ instruments were sampled at $10 \mathrm{~Hz}$ and recorded on a data logger (Model CR5000, Campbell Scientific Inc.) for subsequent processing.

Meteorological parameters included atmospheric temperature and relative humidity (Model HMP45C, Campbell Scientific Inc.), photosynthetically active radiation (Model LI190SB, Licor Inc.), net radiation (Model CNR-1, Kipp \& Zonnen, Delft, The Netherlands) and precipitation (Model 52203, RM Young Inc., Michigan, USA) that were measured at $39.6 \mathrm{~m}$ above the ground. Soil water content was measured at depths of 5, 20, and $50 \mathrm{~cm}$ using automated time domain reflectometry probes (Model CS615-L, Campbell Scientific Inc.). Soil temperatures were measured at five depths (2, 5, 20, 50 and $100 \mathrm{~cm})$ using thermocouples (105T and 107L, Campbell Scientific Inc.). Meteorological variables were sampled at $1 \mathrm{~Hz}$ with 30-min averages calculated by CR10X-TD data loggers (Campbell Scientific Inc.).

REW is defined as:

$$
\mathrm{REW}=\frac{\theta_{m}-\theta_{w p}}{\theta_{f c}-\theta_{w p}}
$$

where $\theta_{m}$ is the soil water content at a soil depth of $0.5 \mathrm{~m}, \theta_{f c}$ is field capacity and $\theta_{w p}$ is wilting point (all in $\mathrm{cm}^{3} \mathrm{~cm}^{-3}$ ). For values of $\theta_{f c}$ and $\theta_{w p}$ refer to Mi et al. (2009). REW was calculated for the single soil depth of $50 \mathrm{~cm}$, as this is approximately the average depth from which the majority of water extraction occurs (Mi et al., 2009).

The fluxes of net ecosystem exchange (NEE, mg CO $\left.\mathrm{m}^{-2} \mathrm{~s}^{-1}\right)$ and ET $\left(\mathrm{g} \mathrm{H}_{2} \mathrm{O} \mathrm{m} \mathrm{s}^{-2}\right)$ were obtained from covariance computed at 30 -min intervals.

$$
F_{\mathrm{NEE}}=\overline{w^{\prime} \rho_{c}^{\prime}\left(z_{r}\right)}+\int_{0}^{z_{r}} \frac{\partial \bar{\rho}_{c}}{\partial t} d z
$$

where $w$ and $\rho_{\mathrm{c}}$ represent vertical velocity and $\mathrm{CO}_{2}$ density, respectively. The overbars denote time averaging and primes represent fluctuations from the mean. The first term on the right-hand side is the eddy flux for $\mathrm{CO}_{2}$ or water vapor, the second term is the storage of $\mathrm{CO}_{2}$ or water vapor below the height of observation $\left(\mathrm{z}_{\mathrm{r}}\right)$, and all advective terms in the mass conservation equation were ignored (Baldocchi, 2003).

Spurious data were removed from the dataset if the instrument performance and experimental conditions were abnormal. Such problems were largely related to rainfall, water condensation, system failure or weak turbulent mixing during the night (Wen et al., 2006). Three-dimensional rotation of the coordinates was applied to the wind components to avoid the effects of instrument tilt or irregular airflow (Aubinet et al., 2000). Corrections were made for the effects of fluctuations of air density on the fluxes of $\mathrm{CO}_{2}$ and water vapor (Webb et al., 1980). Storage below the EC height was also corrected (Hollinger et al., 1994). When the value of friction velocity $(u *)$ was $<0.19 \mathrm{~m} \mathrm{~s}^{-1}$, the values observed of 
NEE and ET in the night (global radiation $<1 \mathrm{~W} \mathrm{~m}^{-2}$ ) were excluded. The energy balance closure was $77 \%$ (Li et al., 2005) and Wen et al. (2005) indicated that the co-spectral and power-spectral distributions both followed theoretical laws, and there was no obvious loss of high-frequency flux.

The gap-filling of the half-hourly ET was performed based on the methods described by Falge et al. (2001), but modified according to the gap-filling methodology of Reichstein et al. (2005), which considers the temporal auto-correlation of ET as well as the covariance of ET with environmental variables. The data gaps of NEE were primarily filled by the nonlinear regression method (Falge et al., 2001). For small gaps $(<2 \mathrm{~h}$ ), the missing data were linearly interpolated. For large gaps, the missing daytime NEE was estimated using the Michaelis-Menten equation with an independent 10-d window (Wen et al., 2010). The nighttime NEE was defined as nighttime ecosystem respiration. The missing nighttime ecosystem respiration was estimated as a function of soil temperature and soil moisture with a yearly interval (Reichstein et al., 2002).

Unfortunately, direct measurements of GPP are usually not available in most ecosystem studies. Following micrometeorological conventions, $\mathrm{C}$ uptake by an ecosystem is denoted by negative values of $\mathrm{CO}_{2}$ flux (NEE), while $\mathrm{C}$ release through ecosystem respiration (RE) is reported as positive values. Thus, $\mathrm{GPP}\left(\mathrm{mg} \mathrm{CO}_{2} \mathrm{~m}^{-2} \mathrm{~s}^{-1}\right)$ can be estimated by subtracting $\mathrm{CO}_{2}$ flux from ecosystem respiration: GPP $=\mathrm{RE}-\mathrm{NEE}$. To estimate GPP, the daytime RE was estimated by extrapolation of the functional relationship between nighttime RE and soil temperature and water content (Wen et al. 2010). Similarly to Ju et al. (2010), we considered the GPP derived from measured NEE, soil temperature and soil water content as measured GPP.

WUE at the ecosystem level, measured as the ratio between daily-integrated GPP and daily-integrated ET, is a useful indicator of the relationship between terrestrial water and $\mathrm{C}$ cycles (Jongen et al., 2011). Daily ecosystem WUE $\left(\mathrm{g} \mathrm{C} \mathrm{kg}^{-1} \mathrm{H}_{2} \mathrm{O}\right)$ is calculated as:

$$
\mathrm{WUE}=\mathrm{GPP} / \mathrm{ET}
$$

WUE expresses the relationship between $\mathrm{C}$ fixation and water consumption during a day. The reciprocal of WUE reflects the water cost per unit $\mathrm{C}$ assimilation during a day. Additionally, annual WUE is defined as the ratio of annual sums of GPP to ET. Daily WUE during the active growing season (June-August) and annual WUE and its control environments were analyzed in this study.

\section{Statistical analysis}

The relationships between GPP, ET and air temperature were fitted with linear $(y=\mathrm{a} x$ $+\mathrm{b})$ and quadratic $\left(y=a x^{2}+b x+c\right)$ equations using the Origin software package. The air temperature when achieving the maximum GPP and ET was obtained by calculating $-b / 2 a$. Pearson's correlation analysis was used to determine the relationship between temperature when GPP achieved the maximum value and the average of REW during 
June-August. The difference of GPP and ET under different soil water conditions was performed by $t$-test using the SPSS software package.

\section{Results}

\section{Environmental conditions}

Figure 1 illustrates the seasonal variation of daily precipitation, REW, daily air temperature and VPD during 2003-2008. Overall, 46.6\% (in 2007) to 59.1\% (in 2003) of the annual rainfall was received during March-June (Fig. la-f). Rainfall in July was only $3.9 \mathrm{~mm}$ in 2003 and $2.7 \mathrm{~mm}$ in 2007, respectively, accounting for 0.5 and $0.2 \%$ of the annual rainfall. Moreover, July had mean daily temperatures of 31.9 and $30.4{ }^{\circ} \mathrm{C}$ in 2003 and 2007, respectively (about $2^{\circ} \mathrm{C}$ more than other years), with the high temperature period corresponding to the summer less-rainy season. Rainfall in July 2004 and 2005 was also relatively less compared to 2006 and 2008, accounting for 7.8 and $4.0 \%$ of annual rainfall, respectively (for 2006 and 2008 the value was about $11 \%$ ).

During the active growing season, there was temporarily low REW $(\leq 0.5)$ except in 2006 (Fig. 1a-f). REW < 0.5 occurred for the longest period in 2003 (36 d), during which time the mean value of REW was 0.33, which was almost the same as in 2007 (0.34 for 25 d). Additionally, REW < 0.5 occurred for 18, 29 and $6 \mathrm{~d}$ in 2004, 2005 and 2008, respectively, during which time average REW (0.44) was greater than in 2003 and 2007. VPD showed a similar pattern in 2003 and 2007, achieving maximum values of $3.9 \mathrm{kPa}$ in summer of 2003 (mid-July) and $3.8 \mathrm{kPa}$ in summer of 2007 (late July) (Fig. $1 g-l$ ). The average VPDs during the active growing seasons of 2003 and 2007 were 2.0 and $1.8 \mathrm{kPa}$, respectively, which were higher than for $2004(1.5 \mathrm{kPa}), 2005(1.6 \mathrm{kPa})$, $2006(1.5 \mathrm{kPa})$ and $2008(1.6 \mathrm{kPa})$. The minimum VPD values (near $0 \mathrm{kPa}$ ) occurred during winter for all years.

Daily temperature progressively increased in February-August and decreased in August-February (Fig. 1g-l). The minimum temperature occurred in January 2003 $\left(-2.3^{\circ} \mathrm{C}\right)$ and the maximum in July $2003\left(34.0^{\circ} \mathrm{C}\right)$.

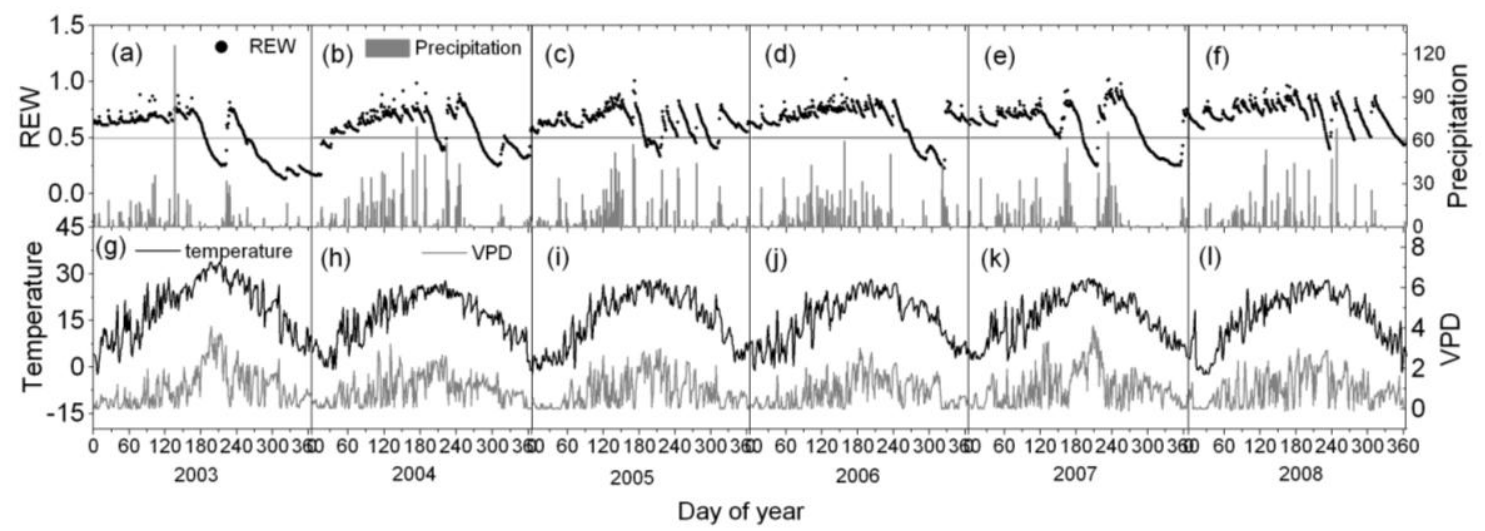

Figure 1. Seasonal and inter-annual variations of daily precipitation $(P)$, soil relative extractable water $(R E W)(a-f)$, daily air temperature and vapor pressure deficit (VPD, 8:00-18:00) ( $g-l)$ during 2003-2008 in a subtropical evergreen coniferous plantation. 


\section{Seasonal variation of WUE and annual WUE}

For most of the time, the variation in WUE was in the range of $1.5-4.5 \mathrm{~g} \mathrm{C} \mathrm{kg}^{-1} \mathrm{H}_{2} \mathrm{O}$. Within any single year, during 2003-2008, a decline in WUE was always observed during June from the seasonal variation of WUE (Fig. 2). Accordingly, the daily WUE formed a trough during the active growing season for all years (Fig. 2).

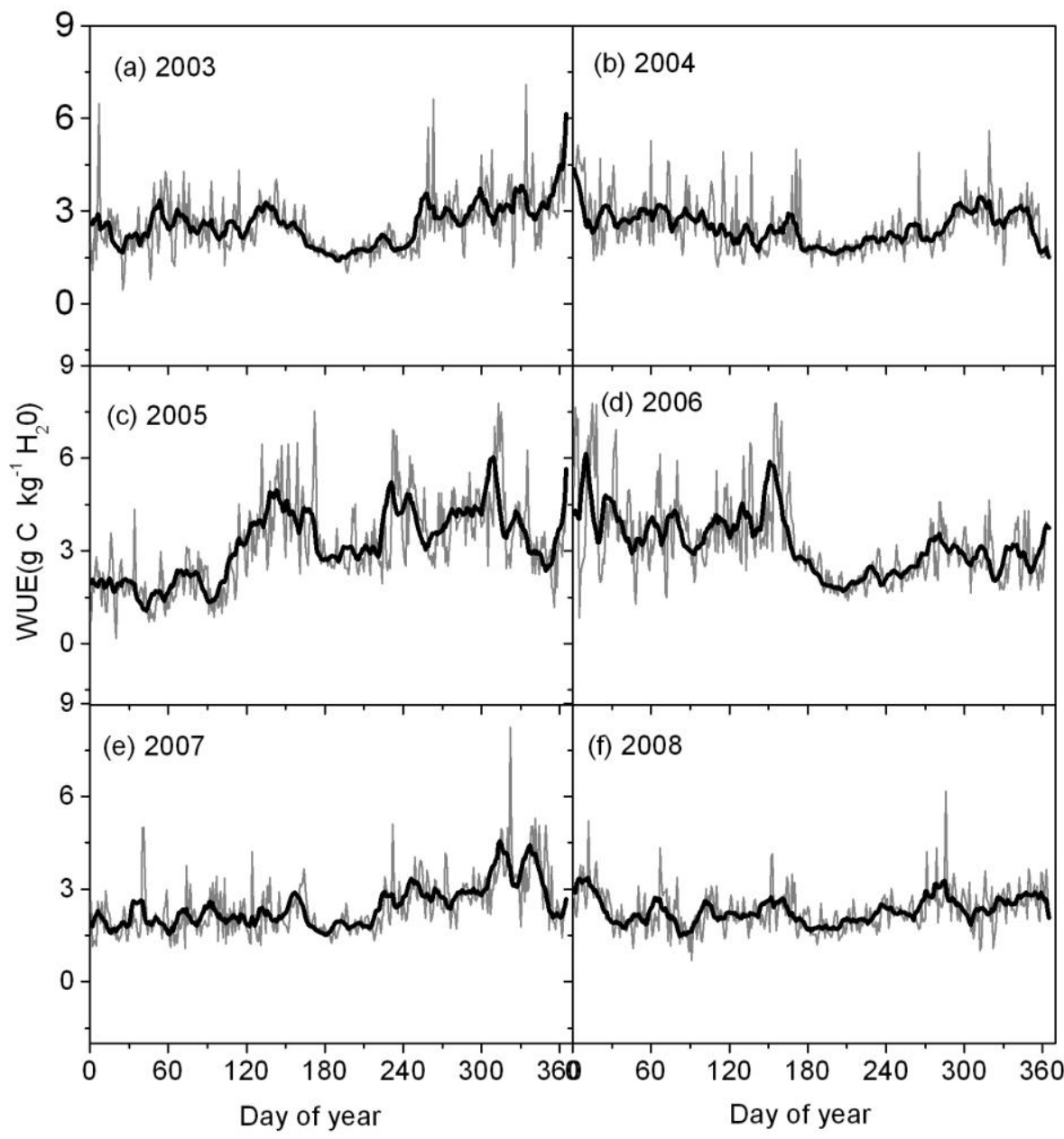

Figure 2. Seasonal and inter-annual variations of water use efficiency (WUE, $\mathrm{g} \mathrm{C} \mathrm{kg}^{-1} \mathrm{H}_{2} \mathrm{O}$ ) during 2003-2008 in a subtropical evergreen coniferous plantation. The black lines are 10-d running means.

Annual WUE (the ratio of annual sums GPP and ET) in 2005 and 2006 (2.7-2.9 gC $\mathrm{kg}^{-1} \mathrm{H}_{2} \mathrm{O}$ ) was higher than for the other four years (2.1-2.2 $\mathrm{gC} \mathrm{kg}^{-1} \mathrm{H}_{2} \mathrm{O}$ ) (Fig. 3). The slope of the linear fit between GPP and ET in 2005 and 2006 was also higher than for the other four years (Fig. 3). As far as the whole year was concerned, annual WUE in the years of poor water conditions during the active growing season (e.g. 2003 and 2007) was consistent with those of 2004 and 2008 (normal years). Annual WUE was in proportion to annual solar radiation for the year 2003 to 2008 (Fig. 4). Annual solar radiation explained $81 \%$ of the variations in annual WUE (Fig. 4). 


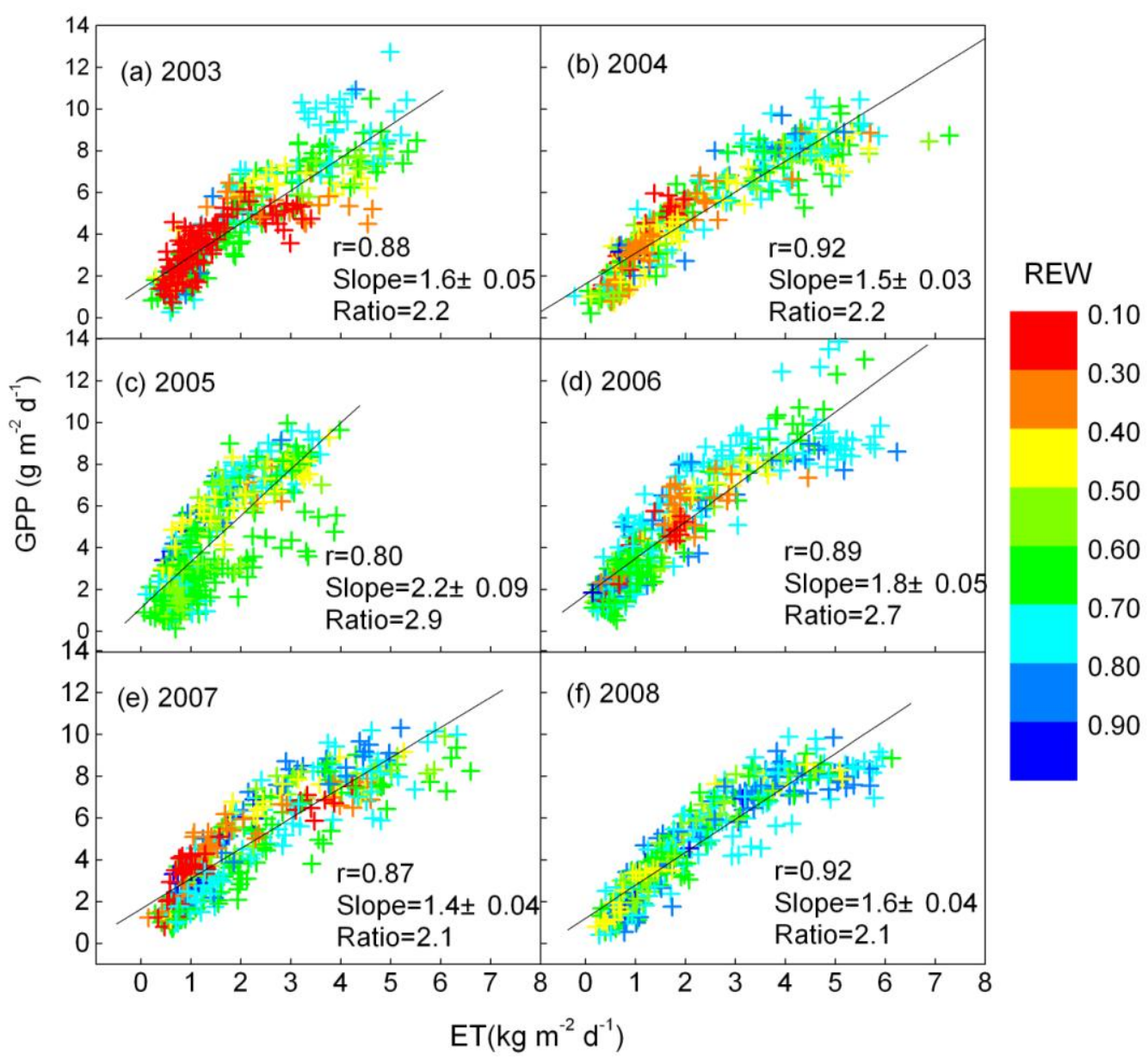

Figure 3. Relationship between GPP and ET during 2003-2008 in a subtropical evergreen coniferous plantation. Also shown are the correlation coefficient, the slope of the linear fit, and the ratio of annual GPP to ET) and the REW on the color scale. All regressions are significant at $P<0.001$.

\section{GPP, ET and WUE under different REW intervals relative to temperature}

Figure 5 compares the responsive characteristics of GPP and ET to air temperature during June-August of 2003-2008. GPP response characteristics to air temperature for all years could be fitted using quadratic equations. The air temperature at which the maximum of GPP $\left(T_{\mathrm{GPP}}\right)$ was achieved could be calculated from the fitted site-specific parameters (see 'Statistical analysis' section). For 2003 and 2007, GPP was depressed when $T_{\mathrm{a}}>26$ and $28^{\circ} \mathrm{C}$ respectively, while in years other than 2003 and 2007, GPP began to decrease when $T_{\mathrm{a}}>30$ or $32^{\circ} \mathrm{C}$ (Table 1). $T_{\mathrm{GPP}}$ was proportional to the average value of REW during June-August $\left(\mathrm{REW}_{6-8}\right)$ and Pearson's correlation coefficient $(\mathrm{r})$ between them was $0.90(P=0.01)$ (Fig. 6). Our results showed that high $T_{\mathrm{a}}\left(>26-32^{\circ} \mathrm{C}\right)$ became a restriction for $\mathrm{C}$ assimilation during the active growing season. The temperature when GPP achieved the maximum $\left(T_{\mathrm{GPP}}\right)$ was significantly $(P=0.015, \mathrm{r}=0.899)$ correlated with $\mathrm{REW}_{6-8}$, indicating that $T_{\mathrm{GPP}}$ was not a constant but a variable determined by soil water conditions and became lower if drought occurred (e.g. in 2003 and 2007). 
Table 1. Temperature when gross primary productivity (GPP) and evapotranspiration (ET) achieved a maximum value during June-August and the average of REW at that time

\begin{tabular}{lcccccc}
\hline & 2003 & 2004 & 2005 & 2006 & 2007 & 2008 \\
\hline $\begin{array}{l}\text { Temperature when GPP achieved the } \\
\text { maximum value }\left(T_{\mathrm{GPP}},{ }^{\circ} \mathrm{C}\right)^{*}\end{array}$ & 26 & 30 & 30 & 32 & 28 & 32 \\
$\begin{array}{l}\text { Temperature when } \mathrm{ET} \text { achieved the } \\
\text { maximum value }\left(T_{\mathrm{ET}},{ }^{\circ} \mathrm{C}\right)^{*}\end{array}$ & 30 & - & - & - & 31 & - \\
$\begin{array}{l}\text { Average REW during June-August } \\
\left(\mathrm{REW}_{6-8}\right)\end{array}$ & 0.547 & 0.663 & 0.603 & 0.762 & 0.640 & 0.755 \\
\hline
\end{tabular}

*This value obtained by calculating -b/2a from the quadratic equation in Fig. 3 .

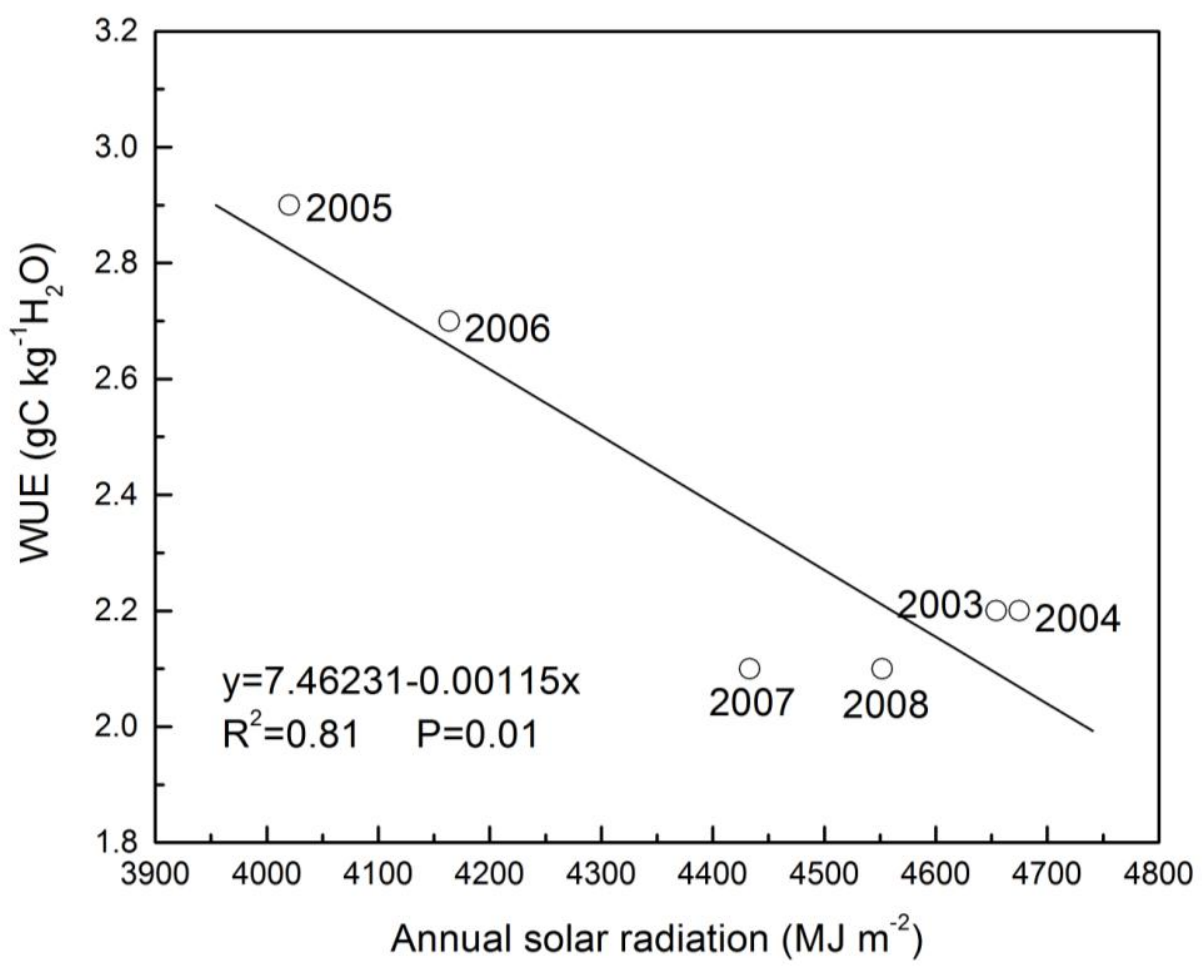

Figure 4. The relationship between annual WUE and annual solar radiation during 2003-2008 in a subtropical evergreen coniferous plantation.

The relationship between $T_{\mathrm{a}}$ and ET could be fitted either by a linear or a quadratic equation (Fig. 5), which was determined by soil water availability. The optimum temperature of ET for 2003 and 2007 was greater than $T_{\mathrm{GPP}}$. For 2003 and 2007, the response characteristics of GPP and ET to $T_{\mathrm{a}}$ suggested that high $T_{\mathrm{a}}\left(>26-28^{\circ} \mathrm{C}\right)$ induced a decrease in GPP and, at higher $T_{\mathrm{a}}\left(>30-31^{\circ} \mathrm{C}\right)$, also induced a decrease in ET, which lagged behind GPP in the active growing season (Table 1). For years other than 2003 and 2007, ET showed a linear increase with temperature although GPP was stable when 
temperature reached around $T_{\mathrm{GPP}}$. Compared to GPP, ET showed an increase (Fig. $5 d, f, h$ and $l$ ) or a lag-decrease (Fig. $5 b$ and $j$ ) when air temperature was higher than $T_{\mathrm{GPP}}$.

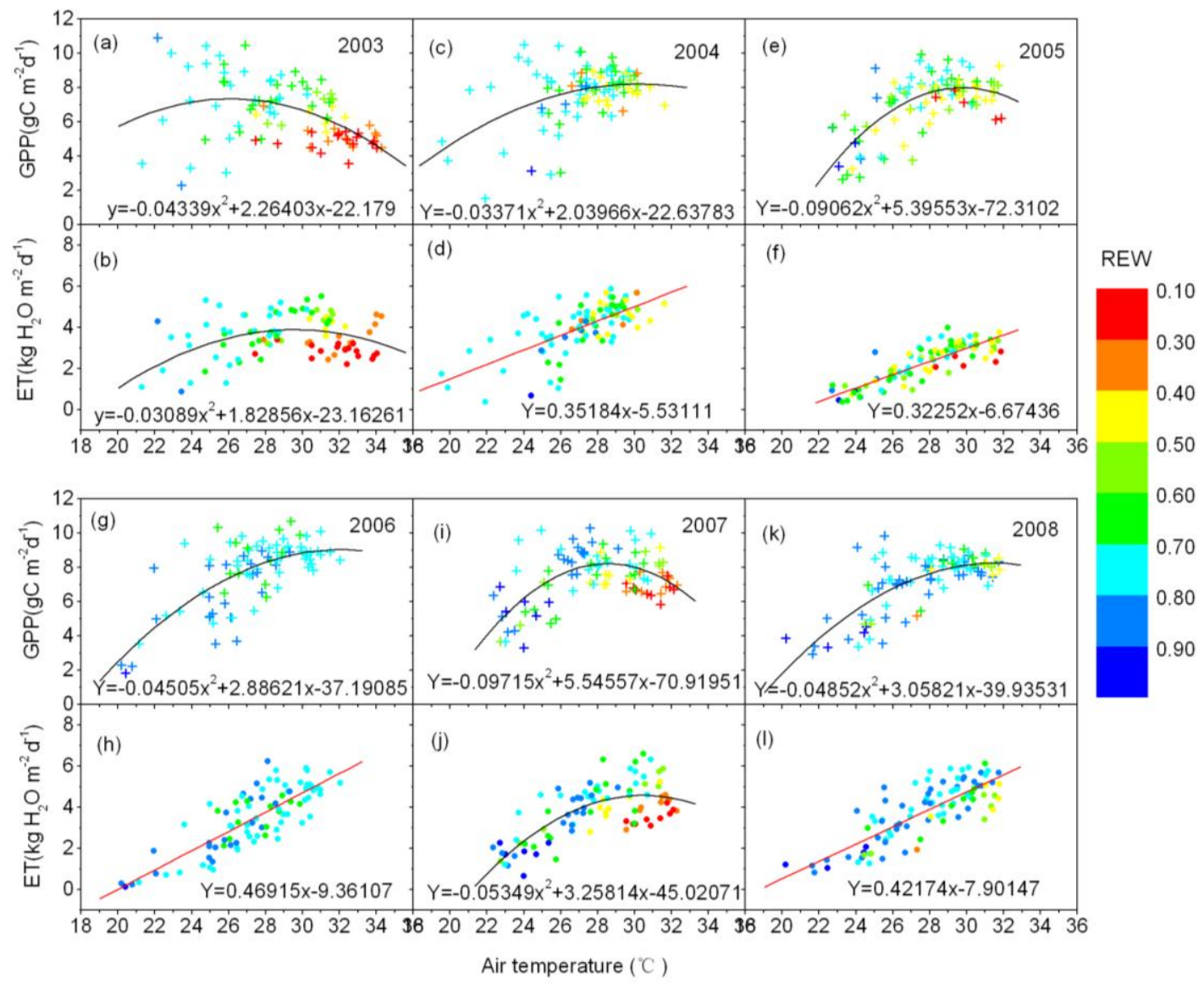

Figure 5. The dependence of gross primary productivity (GPP, $\left.\mathrm{g} \mathrm{C} \mathrm{m}^{-2} \mathrm{~d}^{-1}\right)$ and evapotranspiration (ET, $\mathrm{kg} \mathrm{H}_{2} \mathrm{O} \mathrm{m}^{-2} \mathrm{~d}^{-1}$ ) on air temperature on a daily basis during June-August of 2003-2008 in a subtropical evergreen coniferous plantation. Also shown are the fitting equation according to $y=a x 2+b x+c$ and $y=a x+b$, and REW on the color scale. All fitted equations are $P<0.001$.

The ratio between GPP and ET, i.e. WUE, was also strongly related to $T_{\mathrm{a}}$, decreasing by about $60-70 \%$ when $T_{\mathrm{a}}$ increased from 22 to $32^{\circ} \mathrm{C}$ (Fig. 7). The relationship between $T_{\mathrm{a}}$ and WUE can be expressed by $\mathrm{y}=\mathrm{a}-\mathrm{b} \ln \left(T_{\mathrm{a}}\right)$, which explained $>60 \%(60-78 \%)$ of the variations in daily WUE. The higher WUE in the years 2005 and 2006 was due to lower solar radiation (see 'Discussion').

In the active growing seasons of 2003 and 2007, differences in GPP and ET were observed among different REW intervals when $T_{\mathrm{a}}>T_{\mathrm{GPP}}$ (Table 2). For 2003, GPP when REW $\geq 0.5$ was an average of $7.34 \pm 1.15 \mathrm{~g} \mathrm{C} \mathrm{m}^{-2} \mathrm{~d}^{-1}$. GPP was reduced to $6.26 \pm 0.50 \mathrm{~g}$ $\mathrm{C} \mathrm{m}^{-2} \mathrm{~d}^{-1}$ when $0.4<\mathrm{REW}<0.5$, and to $5.02 \pm 0.60 \mathrm{~g} \mathrm{C} \mathrm{m}^{-2} \mathrm{~d}^{-1}$ when $\mathrm{REW} \leq 0.4$. GPP showed significant differences between REW $\geq 0.5$ and $0.4<\mathrm{REW}<0.5(P<0.05)$, and between $0.4<$ REW $<0.5$ and REW $<0.4(P<0.05)$. ET when REW $\geq 0.5$ and $0.4<$ 
REW $<0.5$ was almost the same (Table 2). There was a significant difference for ET between $0.4<\mathrm{REW}<0.5$ and REW $\leq 0.4(P<0.05)$. In 2007, GPP showed significant differences when REW $\leq 0.4$.

Table 2. GPP and ET under different soil water conditions when $\mathrm{Ta}>26^{\circ} \mathrm{C}$ in 2003 and $\mathrm{Ta}>$ $28^{\circ} \mathrm{C}$ in 2007. Also shown is the average of REW, Ta and the number of days (N) under different REW intervals.

\begin{tabular}{lcccccc}
\hline \multicolumn{1}{c}{ Year } & $\begin{array}{c}\text { Soil water } \\
\text { conditions }\end{array}$ & $\begin{array}{c}\mathrm{GPP} \\
\left(\mathrm{g} \mathrm{C} \mathrm{m}^{-2} \mathrm{~d}^{-1}\right)\end{array}$ & $\begin{array}{c}\mathrm{ET}\left(\mathrm{kg} \mathrm{H}_{2} \mathrm{O}\right. \\
\left.\mathrm{m}^{-2} \mathrm{~d}^{-1}\right)\end{array}$ & $\mathrm{N}$ & $\mathrm{REW}$ & $\overline{T_{\mathrm{a}}}\left({ }^{\circ} \mathrm{C}\right)$ \\
\hline 2003 & $\mathrm{REW} \geq 0.5$ & $7.34 \pm 1.15 \mathrm{a}$ & $4.09 \pm 0.88 \mathrm{a}$ & 38 & 0.66 & 28.9 \\
$T_{\mathrm{a}}>26^{\circ} \mathrm{C}$ & $0.4<\mathrm{REW}<0.5$ & $6.26 \pm 0.50 \mathrm{~b}$ & $4.08 \pm 0.35 \mathrm{a}$ & 7 & 0.45 & 30.8 \\
& $\mathrm{REW} \leq 0.4$ & $5.02 \pm 0.60 \mathrm{c}$ & $3.13 \pm 0.59 \mathrm{~b}$ & 29 & 0.30 & 32.0 \\
2007 & $\mathrm{REW} \geq 0.5$ & $8.40 \pm 0.88 \mathrm{~d}$ & $5.22 \pm 0.83 \mathrm{c}$ & 22 & 0.68 & 29.9 \\
$T_{\mathrm{a}}>28^{\circ} \mathrm{C}$ & $0.4<\mathrm{REW}<0.5$ & $7.79 \pm 0.88 \mathrm{~d}$ & $4.20 \pm 0.57 \mathrm{~d}$ & 7 & 0.44 & 29.0 \\
& REW $\leq 0.4$ & $6.90 \pm 0.50 \mathrm{e}$ & $3.79 \pm 0.53 \mathrm{~d}$ & 18 & 0.31 & 31.1 \\
\hline
\end{tabular}

Means within columns not followed by the same letter are significantly different at $\mathrm{P}<0.05$.

\section{Discussion}

The overall mean annual WUE $\left(2.4 \pm 0.3 \mathrm{gC} \mathrm{kg}^{-1} \mathrm{H}_{2} \mathrm{O}\right.$, mean for six years $)$ in the subtropical evergreen coniferous plantation in the present study was similar to that in a similar latitude $\left(29^{\circ} 45^{\prime} \mathrm{N}\right)$ for evergreen needle-leaved forest $\left(2.35 \mathrm{gC} \mathrm{kg}^{-1} \mathrm{H}_{2} \mathrm{O}\right.$; Clark et al., 2004), but was less than for evergreen needle-leaved forest growing at a higher latitude (2.66-5.42 $\mathrm{gC} \mathrm{kg}^{-1} \mathrm{H}_{2} \mathrm{O}$; Beer et al., 2009). High precipitation (historic mean $1475 \mathrm{~mm}$ ) in the present study site may have caused low WUE. Generally, the Qianyanzhou site is subject to episodic summer droughts. During a study conducted by Wen et al. (2010), there were extremely dry summers in 2003 and 2007. In the present study, we also observed pronounced drought effects on ecosystem fluxes during the active growing seasons in 2003 and 2007, likely driven by a continuous decline in soil water availability and high atmospheric temperature. All of the study years (2006 excluded) had a REW $<0.5$ during the active growing season, but typical seasonal drought was especially long and severe in 2003 and 2007. Drought conditions in 2003 exceeded those in 2007 in terms of both severity and longevity.

The observed threshold for water limitation was about 40-50\% REW, which appears to be consistent for a wide range of ecosystems - crop (Ding et al., 2013), forest (Ruehr et al., 2012; Granier et al., 2007) - and may emerge as a general approximation to identify forests under drought stress (Ruehr et al., 2012). GPP and ET were reduced by drought when REW dropped below ca. 0.4 (Granier et al., 2007). The typical threshold of the REW (40-50\%) inducing drought effects and significant reduction of GPP and ET was confirmed in the present study and whether the GPP was reduced when REW dropped below 0.5 or 0.4 seemed related to $T_{\mathrm{a}}$ (Table 2 ). 


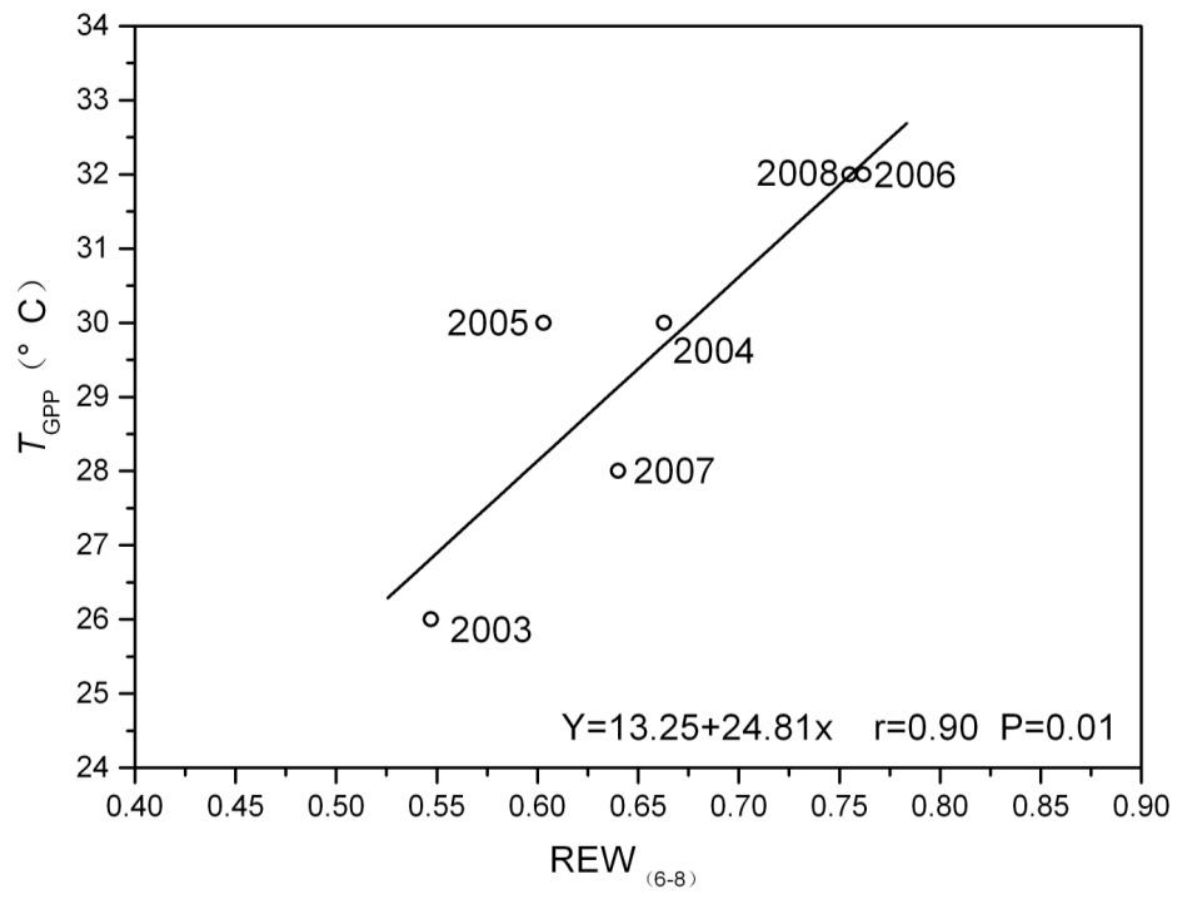

Figure 6. The relationship between average REW during June-August (REW6-8) and air temperature when GPP achieved the maximum (TGPP).

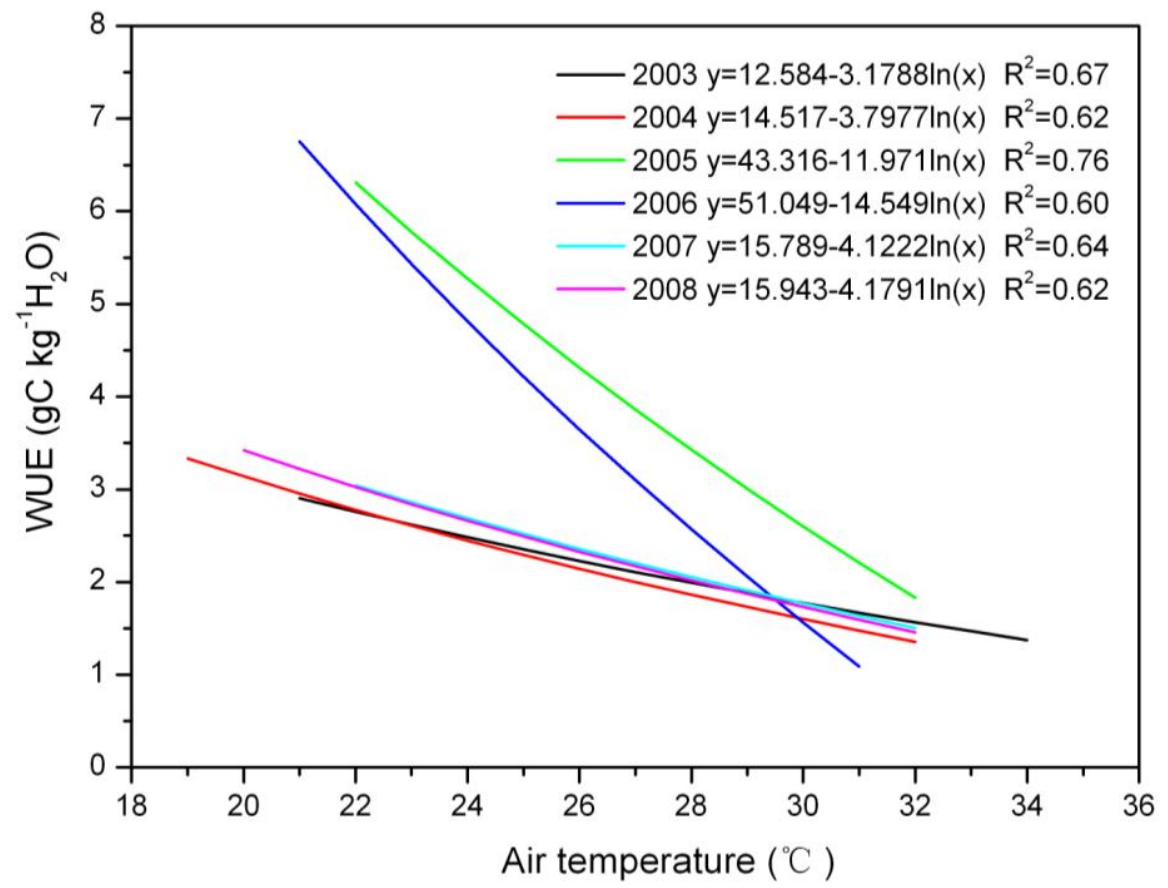

Figure 7. The relationship between water use efficiency (WUE, $\mathrm{g} \mathrm{C} \mathrm{kg}^{-1} \mathrm{H}_{2} \mathrm{O}$ ) and atmospheric temperature $\left(T_{a}\right)$ on a daily basis during the active growing season (June-August) of 2003-2008 in a subtropical evergreen coniferous plantation. WUE vs. air temperature represented by curves of $y=a-b \ln T a$. All curves are significant at $P<0.001$. 
At the stand and ecosystem levels, the variability of WUE results from the trade-off between water loss and $\mathrm{C}$ gain during plant photosynthetic assimilation (Yu et al., 2008). During the studied years (2003-2008), variation of daily WUE in each year formed a trough during the active growing season (Fig. 2). In years other than 2003 and 2007, the linear increasing rate of ET was much larger than that of GPP when $T_{\mathrm{a}}$ was close to $T_{\mathrm{GPP}}$ and the ratio between them (i.e. WUE) was reduced. This phenomenon cannot be interpreted by stomatal limitations to photosynthesis because ET showed no decrease; instead non-stomatal limitations caused by higher temperature (due to either mesophyll conductance or leaf biochemistry or both) can reasonably explain this phenomenon. Proposed non-stomatal mechanisms include reduced RuBisCO activity, reduced electron transport capacity and reduced mesophyll conductance (Flexas et al., 2012; Zhou et al., 2013). The decrease in WUE in response to seasonal drought in 2003 and 2007 may have occurred because higher temperature (larger than optimum) induced reduction in electron transport and carboxylation capacity and restricted $\mathrm{CO}_{2}$ uptake (non-stomatal limitation). Additionally drought constrained leaf photosynthesis (stomatal limitation) caused GPP to decline earlier than ET in response to the seasonal drought (Fig. 5a, b, i, j), which was also observed in a ponderosa pine forest (Ruehr et al., 2012). Similarly, Zhou et al. (2013) stated that stomatal and non-stomatal limitations to photosynthesis must both be considered for the short-term response to drought. To be more specific, $J_{\max }$ (rate of electron transport) is hypothesized to be more sensitive to drought than $V_{\text {cmax }}$ (maximum carboxylation capacity) (Misson et al., 2006) supported by the observations of Wright et al. (2013) that during a drought year the $J_{\max } / V_{\text {cmax }}$ ratio was significantly lower than during a non-drought year.

There are no uniform conclusions on how ecosystem WUE responds to drought - an opinion confirmed by the report of Wright et al. (2013) that the response of WUE to drought was not uniform across sites. WUE increased during drought for two semi-arid pine forests (young and mature) (Vickers et al., 2012) and a young ponderosa pine stand (Ruehr et al., 2012) as water loss was restricted more than the inhibition of photosynthesis. The research of Reichstein et al. (2002) showed that ecosystem WUE decreased during drought at three Mediterranean evergreen sites due to the large decline (by up to 90\%) in light-saturated ecosystem gross C uptake and daytime averaged canopy conductance. For the short-term response to drought, the reduction in WUE observed in some ecosystems should be ascribed to the stomatal and non-stomatal limitations to photosynthesis which decreased more than could be explained by the reduction in stomatal conductance. The results of the present study are consistent with other studies showing that both stomatal and non-stomatal processes are affected by drought (Keenan et al., 2009; Egea et al., 2011). The correlation of $T_{\mathrm{a}}$ with daily WUE (Fig. 7) was greater than for soil water availability (data not shown), suggesting that $T_{\mathrm{a}}$ was a main determinant of variation in daily WUE for this subtropical evergreen coniferous plantation. Reports of increase in WUE during drought have often concerned environments with maximum daily $T_{\mathrm{a}}<20^{\circ} \mathrm{C}$ (e.g. Vickers et al., 2012). Comparably, the study sites that have found decreased WUE during drought have often been for environments with maximum daily $T_{\mathrm{a}}>20^{\circ} \mathrm{C}$ and sometimes $>30^{\circ} \mathrm{C}$ (e.g. Reichstein et 
al., 2002 and Fig. 1). Thus we concluded that $T_{\mathrm{a}}$ may be a factor that determines how daily WUE responds to drought because $T_{\mathrm{a}}$ greatly determines the extent of non-stomatal limitation impacts on photosynthesis. Certainly this conclusion requires validation at a larger regional scale.

At an annual timescale, WUE in 2005 and 2006 was higher than for other years (Fig. 3 ), possibly due to the low annual solar radiation $-10 \%$ below normal at $\sim 400 \mathrm{MJ} \mathrm{m}^{-2}$ (Zhang et al., 2011b) - which caused a disproportionate change in the relationship between evapotranspiration and photosynthesis (Rocha et al., 2004). On an annual time scale, WUE seemed relatively conservative at this study site and tended to increase in years of low solar radiation (Fig. 3c, d). This result is in accordance with the conclusion of Reichstein et al. (2007) who reported that for most sites the year-to-year changes in WUE were small $\left(<1 \mathrm{~g} \mathrm{~kg}^{-1}\right)$. As demonstrated by Yang et al. (2010), different data selection can lead to different conclusions on the relationship between WUE and its controls. For the present study site, at a daily time scale, variations in WUE during the active growing season were determined mostly by air temperature (Fig. 7); while at longer (annual) time scales the variability in WUE may be influenced by solar radiation (Fig. 4). This is attributed to high temperature and drought during the active growing season that induced a shift from optimal stomatal regulation to nonstomatal regulation at leaf scale and affected daily GPP to a large extent, while at longer (annual) time scales solar radiation mostly determined the ET and finally affected annual WUE.

\section{Conclusions}

The following conclusions can be drawn from this study:

(1) GPP and ET did not decrease remarkably and successively during the active growing season (June-August) unless extreme drought had occurred (mean REW < 0.4).

(2) During the active growing season (June-August), the WUE showed a trough, regardless of whether ET was an increasing or decreasing response to seasonal drought. The reduction of water consumption (i.e. ET) in response to high temperature and drought lagged behind the process of $\mathrm{C}$ sequestration (i.e. GPP).

(3) The optimum temperature for GPP to achieve a maximum was related to soil water conditions. Our results demonstrated that the threshold of temperature became lower if drought occurred.

(4) Environmental temperature was a factor that determined the daily WUE response to drought. For the present study site, on a daily time scale, variations in daily WUE during the active growing season were mostly determined by air temperature. At a longer (annual) time scale the influence of solar radiation may be more dominant in controlling the variability of WUE than air temperature.

Acknowledgements. This study was supported by the National Natural Science Foundation of China (31000230, 31290220 and 41305058), the Strategic Priority Research Program - Climate Change: Carbon Budget and Relevant Issues of the Chinese Academy of Sciences (Grant XDA05050601) and the Strategic 
Program of Knowledge Innovation of the Chinese Academy of Sciences (Grant KZCX2-EW-QN305). Data provided by the Qianyanzhou flux site in ChinaFLUX, Key Laboratory of Ecosystem Network Observation and Modeling, Institute of Geographic Sciences and Natural Resources Research, Chinese Academy of Sciences are gratefully acknowledged.

\section{REFERENCES}

[1] Aubinet, M., Grelle, A., Ibrom, A., Rannik, Ü., Moncrieff, J., Foken, T., (2000): Estimates of the annual net carbon and water exchange of European forests: the EUROFLUX methodology. - Adv. Ecol. Res. 30:113-174.

[2] Baldocchi, D.D. (1997): Measuring and modeling carbon dioxide and water vapour exchange over a temperate broad-leaved forest during the 1995 summer drought. - Plant Cell Environ. 20: 1108-1122.

[3] Baldocchi, D.D. (2003): Assessing the eddy covariance technique for evaluating carbon dioxide exchange rates of ecosystems: past, present and future. - Global Change Biology 9: 479-492.

[4] Battaglia, M., Cherry, M.L., Beadle. C.L., Sands, P.J., Hingston, A. (1998): Prediction of leaf area index in eucalypt plantations: effects of water stress and temperature. - Tree Physiol. 18: 521-528.

[5] Beer, C., Ciais, P., Reichstein, M., Baldocchi, D., Law, B.E., Papale, D., Soussana, J.F., Ammann, C., Buchmann, N., Frank, D., Gianelle, D., Janssens, I.A., Knohl, A., Köstner, B., Moors, E., Roupsard, O., Verbeeck, H., Vesala, T.,Williams, C.A., Wohlfahrt, G. (2009): Temporal and among-site variability of inherent water use efficiency at the ecosystem level. - Global Biogeochem. Cycles 23 : GB2018, doi: 10.1029/2008GB003233.

[6] Bernier, P.Y., Bartlett, P., Black TA (2006) Drought constraints on transpiration and canopy conductance in mature aspen and jack pine stands. - Agric. For. Meteorol. 40:64-78.

[7] Bréda, N., Huc, R., Granier A, Dreyer, E. (2006): Temperate forest trees and stands under severe drought: a review of ecophysiological responses, adaptation processes and long-term consequences. - Ann. Forest. Sci. 63: 625-644

[8] Ciais, P.H., Reichstein, M., Viovy, N. et al. (2005) Europe-wide reduction in primary productivity caused by the heat and drought in 2003 - Nature 437:529-533.

[9] Clark, K., Gholz, H., Castro, M. (2004): Carbon dynamics along a chronosequence of slash pine plantations in north Florida.- Ecol. Appl. 14:1154-1171.

[10] Ding, R.S., Kang, S.Z., Li, F.S., Zhang, Y.Q., Tong, L. (2013): Evapotranspiration measurement and estimation using modified Priestley-Taylor model in an irrigated maize field with mulching. - Agric. For. Meteorol. 168: 140-148.

[11] Eamus, D., Prior, L.D. (2001): Ecophysiology of trees of seasonally dry tropics: Comparisons among phonologies. - Adv. Ecol. Res. 32:113-197.

[12] Egea, G., Verhoef, A., Vidale, P.L. (2011): Towards an improved and more flexible representation of water stress in coupled photosynthesis-stomatal conductance models. Agric. For. Meteorol. 151: 1370-1384.

[13] Falge, E., Baldocchi, D, Olson, R et al. (2001): Gap filling strategies for long term energy flux data sets. - Agric. For. Meteorol. 107: 71-77.

[14] Flexas, J., Barbour, M.M., Brendel, O., Cabrera, H.M., Carriquí, M., Díaz-espejo, A.,Douthe, C., Dreyer, E., Ferrio, J.P., Gago, J., Gallé, A., Galmés, J., Kodama, N., Medrano, H., Niinemets, Ü., Peguero-pina, J.J., Pou, A., Ribas-carbó, M., Tomás, M., Tosens, T., Warren, C.R.(2012) Mesophyll diffusion conductance to CO2: An unappreciated central player in photosynthesis.- Plant. Sci. 194:70-84.

[15] Granier, A., Reichstein, M., Bréda, N. (2007): Evidence for soil water control on carbon and water dynamics in European forest during the extremely dry year: 2003. - Agric. For. Meteorol. 143: 123-145.

[16] Grant, R.F., Arain, A., Arora, V., Barr, A., Black, T.A.,Chen, J., Wang, S., Yuan, F., Zhang, 
Y. (2005): Intercomparison of techniques to model high temperature effects on $\mathrm{CO} 2$ and energy exchange in temperate and boreal coniferous forests, - Ecological Modelling 188: 217-252.

[17] Grant,R.F.,Goulden, M.L., Wofsy, S.C., Berry, J.A. (2001): Carbon and energy exchange by a black spruce - moss ecosystem under changing climate: testing the mathematical model ecosys with data from the BOREAS experiment. - J. Geophys. Res. 106: 33605-33621.

[18] Grelle, A., Lindroth, A., Mölder, M. (1999): Seasonal variation of boreal forest surface conductance and evaporation. - Agric. For. Meteorol. 98-99: 563-578.

[19] Griffis, T.J., Black, T.A., Morgenstern, K., Barr, A.G., Nesic, Z. Drewitt, G.B. Gaumont-Guay, G., McCaughey, J.H.(2003): Ecophysiological controls on the carbon balances of three southern boreal forests. -Agric For Meteorol 117: 53-71.

[20] Harley, P.C., Tenhunen, J.D. (1991): Modelling the photosynthetic response of C3 leaves to environmental factors. - In: Boote, K.J., Loomis, R.S. (eds.) Modelling crop photosynthesis-from biochemistry to canopy. Madison, WI, USA: American Society of Agronomy and Crop Science Society of America pp 17-39.

[21] Hoff, C., Rambal, S. (2003): An examination of the interaction between climate, soil and leaf area index in a Quercus ilex ecosystem. - Ann. For. Sci. 60:153-161.

[22] Hollinger, D.Y., Kelliher, F.M., Byers, J.N., Hunt, J.E., McSeveny, T.M., Weir, P.L. (1994): Carbon dioxide exchange between an undisturbed old-growth temperate forest and the atmosphere. - Ecology 75:134-150.

[23] Jongen, M., Pereira, J.S., Aires, L.M., Pio, C.A. (2011): The effects of drought and timing of precipitation on the inter-annual variation in ecosystem-atmosphere exchange in a Mediterranean grassland. - Agric. For. Meteorol. 151: 595-606.

[24] Ju, W., Wang, S., Yu, G., Zhou, Y., Wang, H. (2010): Modeling the impact of drought on canopy carbon and water fluxes for a subtropical evergreen coniferous plantation in southern China through parameter optimization using an ensemble Kalman filter. Biogeosciences 7: 845-857.

[25] Keenan, T., Garcia, R., Friend, A.D.,Zaehle, S., Gracia, C., Sabatéi Jorba, S. (2009): Improved understanding of drought controls on seasonal variation in Mediterranean forest canopy $\mathrm{CO}_{2}$ and water fluxes through combined in situ measurements and ecosystem modelling. - Biogeosciences 6: 1423-1444.

[26] Law, B., Falge, E., Gu, L. et al. (2002): Environmental controls over carbon dioxide and water vapour exchange of terrestrial vegetation. - Agric. For. Meteorol. 113: 97-120.

[27] Li, Z.Q., Yu, G.R., Wen, X.F., Zhang, L.M. Ren, C.Y., Fu, Y.L. (2005): Energy balance closure at ChinaFLUX sites. - Sci. China Ser. D 48: 51-62.

[28] Linares, J.C. and Camarero, J.J. (2012): From pattern to process: linking intrinsic water-use efficiency to drought-induced forest decline. - Global Change Biol. 18: $1000-1015$.

[29] Méthy, M., Gillon, D., Houssard, C. (1997): Temperature-induced changes of photosystem II activity in Quercus ilex and Pinus halepensis. - Can. J. For. Res. 27: $31-38$.

[30] Mi, N., Yu, G.R., Wang, P.X., Wen, X.F., Sun, X.M. (2006): A preliminary study for spatial representativeness of flux observation at ChinaFLUX sites. - Sci. China Ser. D. 49: $24-35$.

[31] Mi, N., Yu, G.R., Wen, X.F., Sun, X.M., Wang, S.S., Zhang, L.M., Song, X. (2009): Use of ecosystem flux data and a simulation model to examine seasonal drought effects on a subtropical coniferous forest. - Asia-Pac. J. Atmos. Sci. 45: 207-220.

[32] Misson, L., Tu, K.P., Boniello, R.A., Goldstein, A.H. (2006): Seasonality of photosynthetic parameters in a muti-specific and vertically complex forest ecosystem in the Sierra Nevada of California. - Tree Physiology 26: 729-741.

[33] Niu, S.L., Xing, X.R., Zhang, Z., Xia, J.Y., Zhou, X.H., Song,B., Li, L.G., Wan, S.Q. (2011): Water-use efficiency in response to climate change: from leaf to ecosystem in a temperate steppe. - Global Change Biol. 17: 1073-1082

[34] Ohta, T., Hiyam, T., Tanaka, H., Kuwada, T., Maximov, T.C., Ohata, T., Fukushima, Y. 
(2001): Seasonal variation in the energy and water exchanges above and below a larch forest in eastern Siberia. - Hydrol. Proc. 15:1459-1476.

[35] Reichstein, M., Ciais, P., Papale, D. (2007): Reduction of ecosystem productivity and respiration during the European summer 2003 climate anomaly: a joint flux tower, remote sensing and modeling analysis. - Global Change Biol. 13: 634-651

[36] Reichstein, M., Falge, E., Baldocchi, D. et al. (2005): On the separation of net ecosystem exchange into assimilation and ecosystem respiration: review and improved algorithm. Global Change Biol. 11: 1424-1439.

[37] Reichstein, M., Tenhunen, J.D., Roupsard, O., Ourcival, J., Rambal, S., Miglietta, F., Peressotti, A., Pecchiari, M., Tirone, G., Valentini, R. (2002): Severe drought effects on ecosystem $\mathrm{CO}_{2}$ and $\mathrm{H}_{2} \mathrm{O}$ fluxes at three mediterranean sites: revision of current hypothesis? - Global Change Biol. 8: 999-1017.

[38] Rocha, A.V., Su, H.B., Vogel, C.S., Schmid, H.P. Curtis, P.S. (2004): photosynthetic and water use efficiency responses to diffuse radiation by an aspen-dominated northern hardwood forest. - Forest Science 50: 793-801

[39] Ruehr, N.K., Martin, J.G., Law, B.E. (2012): Effects of water availability on carbon and water exchange in a young ponderosa pine forest Above- and belowground responses. Agric. For. Meteorol. 164: 136-148

[40] Schulze, E.D., Beck, E., Müller-Hohenstein, K. (2005): Plant Ecology. Berlin/ Heidelberg: Springer

[41] Schulze, E.D., Robichaux, R.H., Grace, J., Rundel, P.W., Ehleringer, J.R. (1987): Plant water balance. - BioScience 37: 30-37

[42] Sun, X.M., Wen, X.F., Yu, G.R., Liu, Y., Liu, Q. (2006): Seasonal drought effects on carbon sequestration of a mid-subtropical planted forest of southeastern China. - Sci. China Ser. D. 49: 110-118.

[43] Vickers, D., Thomas, C.K., Pettijohn, C., Martin, J.G., Law, B.E. (2012): Five years of crbon fluxes and inherent water-use efficiency at two semi-arid pine forests with different disturbance histories. - Tellus B 64, 17159

[44] Wang, S. (2012): Evaluation of Water Stress Impact on the Parameter Values in Stomatal Conductance Models Using Tower Flux Measurement of a Boreal Aspen Forest. - Journal of Hydrometeorology 13: 239-254.

[45] Wang, S., Yang, Y., Trishchenko, A.P., Barr, A.G., Black, T.A., Mccaughey, H. (2009): Modelling the response of canopy stomatal conductance to humidity. - Journal of Hydrometeorology 10: 521-532.

[46] Wang, S.Q., Liu, J.Y., Yu, G.R., Pan, Y.Y. (2004): Effects of land use change on the storage of soil organic carbon: A case study of the Qianyanzhou Forest Experimental Station in China - Climate Change 67: 247-255.

[47] Webb, E.K., Pearman, G.I., Leuning, R. (1980): Correction of flux measurement for density effects due to heat and water vapor transfer. - Quart. J. Roy. Meteor. Soc. 106: $85-100$.

[48] Wen, X.F., Yu, G.R., Sun, X.M., Liu, R.F. (2005): Turbulence flux measurement above the overstory of a subtropical Pinus plantation over the hilly region in southeastern China. Sci. China Ser. D. $48: 63-73$.

[49] Wen, X.F., Wang, H.M., Wang, J.L., Yu, G.R., Sun, X.M. (2010): Ecosystem carbon exchanges of a subtropical evergreen coniferous plantation subjected to seasonal drought, 2003-2007. - Biogeosciences 7: 357-369.

[50] Wen, X.F., Yu, G.R., Sun, X.M., LI, Q.K., Liu, R.F. (2006): Soil moisture effects on the temperature dependence of ecosystem respiration in a subtropical pinus plantation of southeastern China. - Agric. For. Meteorol. 137: 166-175.

[51] Wright, J.K., Williams, M., Starr, G., Mcgee, J., Mitchell, R.J. (2013): Measured and modelled leaf and stand-scale productivity across a soil moisture gradient and a severe drought. -Plant, Cell and Environment 36: 467-483.

[52] Yang, B., Pallardy, S.G., Meyers, T.P., Gu, L.H., Hanson, P.J., Wullschleger, S.D., Heuer, M., Hosman, K.P., Riggs, J.S., Sluss, D.W. (2010): Environmental controls on water use efficiency during severe drought in an Ozark Forest in Missouri, USA .- Global Change 
Biol. 16:2252-2271.

[53] Yu, G.R., Song, X., Wang, Q.F., Liu, Y.F., Guan, D.X., Yan, J.H. Sun, X.M., Zhang, L.M., Wen, X.F. (2008): Water-use efficiency of forest ecosystems in eastern China and its relations to climatic variables. - New Phytol. 177: 927-937.

[54] Zhang, W.J., Wang, H.M., Wen, X.F., Yang, F.T., Ma, Z.Q., Sun, X.M., Yu, G.R. (2011a): Freezing-induced loss of carbon uptake in a subtropical coniferous plantation in southern China. - Ann. Forest Sci. 68:1151-1161.

[55] Zhang, W.J., Wang, H.M., Yang, F.T., Yi, Y.H., Wen, X.F., Sun, X.M., Yu, G.R., Wang, Y.D., Ning, J.C. (2011b): Underestimated effects of low temperature during early growing season on carbon sequestration of a subtropical coniferous plantation. - Biogeosciences 8:1667-1678.

[56] Zhang, Y., Grant, R.F., Flanagan, L.B., Wang, S., Verseghy, D.L. (2005): Modelling $\mathrm{CO}_{2}$ and energy exchange in a northern semiarid grassland using the carbon- and Nitrogen-coupled Canadian Land Surface Scheme (C-CLASS). - Ecol. Model. 181: 591-614.

[57] Zhou, S.X., Duursma, R. A., Medlyn, B. E., Kelly, W.G., Prentice, I.C. (2013): How should we model plant response to drought? An analysis of stomatal and non-stomatal responses to water stress.- Agriculture and Forest Meteorology 182-183: 204-214. 